\title{
Preliminary behavioural study of Caballo Fino Chilote stallions with restricted access to space and water during summer
}

\author{
Estudio preliminar del comportamiento de potros raza Caballo Fino Chilote \\ con acceso restringido a espacio y agua durante el verano \\ TA Tadich ${ }^{\mathbf{b}}{ }^{*}$, RG Pulido ${ }^{\mathrm{b}}$
}

\author{
aBecario CONICYT, Programa Doctorado en Ciencias Veterinarias, \\ Facultad de Ciencias Veterinarias, Universidad Austral de Chile, Valdivia, Chile. \\ bInstituto de Ciencia Animal, Facultad de Ciencias Veterinarias, \\ Universidad Austral de Chile, Valdivia, Chile.
}

\begin{abstract}
RESUMEN
El Caballo Fino Chilote (CFCh) es la única raza de pony chileno y un recurso genético único. Un grupo de 7 potros CFCh fue observado por 60 horas, durante el verano, en la estación experimental del INIA-Butalcura, Isla de Chiloé, bajo condiciones de restricción de espacio y agua. El método de muestreo por escaneo se utilizó cada 5 minutos para evaluar estados conductuales y focal continuo para los eventos. Se registraron 5 estados y 19 eventos conductuales. Las interacciones entre potros tuvieron una frecuencia de presentación baja, siendo la más común "evasión" con un promedio de $1,2$ eventos por potro por día. Los equinos utilizaron un 55,89\% ( \pm 4,3\%) del tiempo en forrajear, $2,5 \%( \pm 0,82 \%)$ en locomoción, 7,26\% ( $\pm 0,82 \%)$ de pie alerta, $32,24 \%( \pm 2,7 \%)$ descansando y $1,86 \%( \pm 0,64)$ en otras actividades. Forrajeo fue la principal actividad, siendo significativamente más baja $(\mathrm{P}<0,05)$ durante el mediodía, periodo donde el descanso fue significativamente mayor $(\mathrm{P}<0,05)$ comparado con los periodos de mañana y tarde. Se encontró una correlación positiva significativa entre temperatura y descanso y una correlación negativa significativa entre temperatura y forrajeo. Este estudio es la primera descripción conductual de potros de raza CFCh; la distribución de sus actividades es comparable a la de otras razas mantenidas en sistemas de pastoreo. Se enfatiza que la restricción de acceso a agua a la cual estaban sujetos estos animales es preocupante desde el punto de vista ético poniendo en riesgo su bienestar. Se requieren más estudios conductuales de esta raza para clasificarla de acuerdo a su temperamento y posibles usos.
\end{abstract}

Key words: Caballo Fino Chilote, horse, stallion, behaviour, Chile.

Palabras clave: Caballo Fino Chilote, potros, conducta, Chile.

\section{INTRODUCTION}

In Chile the most popular horse breed is the "Caballo Criollo Chileno" for which pedigree information can be traced back to 1893 (Pinochet 1980). There is a second Chilean horse breed; the "Caballo Fino Chilote" (CFCh). This breed is related to the Archipiélago of Chiloé located between $41^{\circ}$ and $43^{\circ}$ of south latitude. The island has an oceanic temperate rainy climate, with medium annual temperatures of $11^{\circ} \mathrm{C}$ (Sánchez and Morales 2000).

The CFCh is a unique equine resource; morphological characteristics (Voeltz 1996, Escobar and Tadich 2006) and a genetic analysis (Barrera 1998) confirm that its origins comes from those equines from the Península Ibérica brought by the Spaniard conquerors between the XVI and XVII centuries (Escobar et al 1998, Mujica et al 2005) with a close relationship with the "Garrano" horse from Portugal (Mujica et al 2005). The main importance of the CFCh is that it is considered the only pony with Spanish origins

Accepted: 17.03.2010.

* Casilla 567, Valdivia, Chile; tamaratadich@uach.cl subsisting in South America (Cothran et al 1993). Records for the CFCh can be found since 1999 when the stud book was opened as a result of a conservation program (FIA 2000). It has an average height to the withers of $120 \mathrm{~cm}$ (Voeltz 1996) and an average weight of $218 \mathrm{~kg}$ for stallions and $247 \mathrm{~kg}$ for mares (Mujica et al 2005).

The breed is known for being alert with excellent temperament (Escobar et al 1998). It has also been described as a rustic, strong and tame horse (Mujica et al 2005), and with biokinematic characteristics, such as stride and step length, and conformational parameters, suitable for its use in hipotherapy (Escobar and Tadich 2006), although there are no studies about the breed's behaviour.

Animals in natural conditions are regarded as showing the normal behaviour of that species (Christensen et al 2002). Time budgets assess objectively important aspects of behaviour (Fraser 1992) such as amount of time involved in them and their distribution according to time of day or season. Diurnal studies of the time budgets of domestic horses on pasture, and of free-ranging feral horses, have been conducted by Schoen et al (1976), Salter and Hudson (1979), Crowel-Davis (1983), Kaseda (1983) and Sweeting et al (1985). Behavioural information about Chilean breeds 
is scarce, for this reason the objective of this study was to perform a preliminary study of some behavioural aspects of CFCh stallions kept on pasture in their natural habitat (Chiloé Island) during summer, under typical management conditions used for this breed.

\section{MATERIAL AND METHODS}

A group of seven CFCh stallions, kept at the National Institute of Agricultural Research (INIA) located in Butalcura, Chiloé Island was studied. Stallions at INIA are kept together on pasture, in a reduced area of 1 hectare. No handling is done with them since they are kept only as a genetic resource.

The group was observed between 08:00 $\mathrm{h}$ and 20:00 $\mathrm{h}$ between the $27^{\text {th }}$ of February and $2^{\text {nd }}$ of March of 2008 (summer season). During this period, except for the presence of the observer, no human contact occurred. Stallions were kept with no ad libitum access to water (not recommended) and with no mares in the vicinity of the enclosure. They were taken to a water source once daily after observation hours, being this the normal management routine used at the station. They had been kept in this area prior to the beginning of the study.

Stallions were identified by natural marks. Observations were conducted by one observer from a distance between 15-20 $\mathrm{m}$ to avoid influencing the horses' behaviour. Average temperatures and relative humidity were registered through the meteorological unit located at the research station.

Five mutually exclusive behavioural states were recorded by scan sampling every five minutes. These behavioural states were foraging, resting, standing alert, locomotion, and other behaviours and are defined in table 1 (1-5). Foraging was categorized into grazing and browsing while resting was categorized into rest standing and rest recumbent.

To assess male related and inter-male interactions, 19 behavioural events were registered (table 1, 6-24) using continuous focal sampling.

The twelve hour observation period was subdivided into three periods: 08:00-12:00; 12:00-16:00 and 16:0020:00 h. These intervals divided the day into a morning, midday and afternoon periods.

The body condition score (BCS) of each horse was recorded once at the beginning of the study using the body condition scoring index for horses from 0 (very poor) to 5 (very fat), based on the Carroll and Huntington (1988) method. The age of stallions was provided by INIA.

Data analysis: Differences in percentage of time dedicated to each behavioural state, between and within stallions and between different periods of the day, among the 5 days of observation, were analyzed by One-Way Analysis of Variance. In cases where data was not normally distributed, according to the Shapiro Wilk test, a Kruskal Wallis test was applied. For assessing correlations between temperature and each of the five behavioural states studied, a Pearson's correlation was coefficient obtained. Behavioural events are presented in terms of total occurrence, average frequency per day and standard deviation. All calculations were made in the computer software STATISTIX $®$ 8. A significance level of $\mathrm{P}<0.05$ was applied.

\section{RESULTS AND DISCUSSION}

The geographical location where the study took place (Butalcura, Chiloé Island) corresponds to the original conditions in which this breed has developed, since it was first introduced by the Spanish conquerors (Cabrera 1945, Escobar et al 1998, Mujica et al 2005). The average temperatures of $18.7^{\circ} \mathrm{C}\left(4.5^{\circ} \mathrm{C}\right.$ min and $29.4^{\circ} \mathrm{C}$ max $)$ and average relative humidity $(57.9 \%)$ registered during the period of observation were normal for the period (Sánchez and Morales 2000).

Social status and nutritional condition have been described as linked to the biological rhythm of an individual (Souris et al 2007). The 7 stallions observed ranged between 4 and 14 years of age (average 9 years), 6 of them had a BCS of 3 (good) and only one had a score 2 (moderate).

For horses living in natural social units, interactions among stallions comprise a prominent feature of social behaviour, ranging from peaceful and cooperative to sparring (McDonnell 2003). Some male related and inter-male interactions observed in the $\mathrm{CFCh}$ stallions are summarised in table 2. Avoidance behaviour was more frequent ( 1.20 events per day per stallion) than aggressive interactions such as biting, boxing or lunging (0.03, 0.37 and 0.03 events per stallion per day respectively) (figure 1). Positive interactions such as allogroom and play were also observed (table 2). Christensen et al (2002) registered a higher number of social interactions in naturally reared and mixed age group of Przewalski stallions than in a domestically reared and of similar age group of stallions. Although the restricted space (1ha) a low number of interactions was found in the present study (table 2). This could be a result of the small size of the group of stallions, of similar ages and the fact that it has been conformed over a long period of time, since according to Boyd and Houpt (1994) the dominance relationship in a group depend on these characteristics; or the fact that they had enough resources to supply their biological needs and that there were no mares present, since aggression may be induced by competition for limited resources (Christensen et al 2002). Another reason for the low frequencies of interactions found could be some intrinsic characteristics of the breed, which has been described as having good temperament (Escobar et al 1998), but this would need further studies to assure.

Over the period monitored, the group of stallions studied spent $55.89 \%( \pm 4.3)$ of the time foraging, $32.4 \%$ $( \pm 2.7)$ resting, $7.26 \%( \pm 2.04)$ standing alert, $2.54 \%$ $( \pm 0.82)$ in locomotion and for $1.86 \%( \pm 0.64)$ of their time they were involved in other activities (table 3 ). This 
Table 1. Ethogram of the behaviours recorded based on Christensen et al (2002), McDonnell (2003) and Souris et al (2007).

Etograma de las conductas observadas, basado en Christensen et al (2002), McDonnell (2003) y Souris et al (2007).

Behaviour Description

1. Foraging

Grazing: Ingest grassy vegetation. With the lips and tongue, vegetation is gathered into the mouth, broken off usually in clumps by jerking the jaw while chewing, and swallowed.

Browsing: Ingest woody plants.

2. Resting Rest Standing: Standing inactive in a relaxed posture, usually with head slightly lowered, eyes partly or nearly closed, and often bearing weight on three legs (one hind leg slightly flexed). With deeper drowsiness (transition between wakefulness and sleep), the lips relax and the ears rotate laterally.

Rest recumbent: Rest or sleep while lying down with head up or legs and head outstretched.

3. Standing alert

Rigid stance with the neck elevated and the head oriented toward the object or animal of focus. The ears are held stiffly upright and forward, and the nostrils may be slightly dilated.

4. Locomotion Walk trot or gallop with a minimum duration of 10s. The horse is not involved in grazing.

5. Other behaviours All other behaviours, e.g. social behaviours, urination, defecation, inter-male interactions, etc.

6. Roll

Dropping from standing to sternal recumbency, then rotating one or more times from sternal to dorsal recumbency, tucking the legs against the body. Typically occurs on dusty or sandy areas.

7. Autogroom

8. Allogroom

9. Stomp

10. Avoidance

11. Posturing

12. Lunge

13. Push

14. Bite threat

15. Bite

16. Strike threat

17. Boxing

18. Chase

Nibbling, biting, licking, or rubbing a part of the body.

Reciprocal coat care in which the partners stand beside one another, usually head to shoulder or head to tail, grooming each other's neck, mane, rump or tail by gently nipping, nuzzling, or rubbing.

Raising and lowering of a foreleg to strike the ground sharply, usually repeatedly.

Movement that maintains or increases an individual's distance from an approaching stallion. The head is usually held low and ears turned back. The retreat can be at any gait but usually occurs at trot.

Pre-fight head-bowing, prancing, stomping, olfactory investigation, as well as stiffening of the entire body, including forelegs. The arched neck threat is also a major component, being held through out most of the interaction.

Swift forward thrust of the body from the rear position or charge from close range toward another stallion (usually toward his fore body), most often displayed concurrently with a bite threat, with ears pinned.

Pressing of the head, neck, shoulder, chest, or body against another horse, causing it to move one or more legs to regain balance.

Bite intention movement with ears back and neck extended, with no actual contact.

Opening and rapid closing of the jaws with actual contact to another horse's body.

A strike motion that appears abbreviated or gestured so as to miss contacting the opponent, often a part of ritualized interactions between stallions.

Two stallions in close proximity simultaneously rearing and striking out toward one another with alternate forelegs.

Pursuit of another stallion, usually at a gallop in an apparent attempt to overtake, direct the movement of, or catch up with the pursued stallion. The pursuing stallion usually pins the ears, exposes the teeth, and bites at the pursued stallions rump and tail.

19. Herding

Combination of head threat and ears laid back with forward locomotion, apparently directing the movement of another stallion(s).

20. Defecate over Defecation on faecal piles in a characteristic sequence: sniff faeces, step forward. Defecate, pivot or back up, and sniff faeces again.

21. Flehmen Head elevated and neck extended, with the eyes rolled back, the ears rotated to the side, and the upper lip everted exposing the upper incisors and adjacent gums while drawing air and fluids through the teeth.

22. Play Play directed at another individual, which may or may not reciprocate; includes low intensity play movements such as nipping, nuzzling, or rubbing.

23. Body sniff Olfactory investigation. A horse sniffs the neck, withers, flank, or tail of another horse, which may or not reciprocate.

24. Displacement Approach of one horse with ears back causes another to move away so that distance is maintained or increased, without overt aggression. 
Table 2. Total occurrence by stallion, average and standard deviation by stallion and daily frequency by stallion for the behavioural events observed. conductuales.

Presentación total por potro, promedio por potro y desviación estándar y frecuencia de ocurrencia diaria por potro de eventos

\begin{tabular}{|c|c|c|c|c|c|c|c|c|c|c|}
\hline \multirow{2}{*}{ Behavioural event } & \multicolumn{7}{|c|}{ total occurrence by stallion } & \multirow[b]{2}{*}{ total } & \multirow{2}{*}{$\begin{array}{l}\text { average by } \\
\text { stallion }\end{array}$} & \multirow{2}{*}{$\begin{array}{c}\text { frequency } \\
\text { by day }\end{array}$} \\
\hline & 1 & 2 & 3 & 4 & 5 & 6 & 7 & & & \\
\hline roll & 4 & 3 & 7 & 1 & 2 & 0 & 3 & 20 & $2.86 \pm 2.27$ & 0.57 \\
\hline autogroom & 9 & 2 & 8 & 8 & 9 & 5 & 2 & 43 & $6.14 \pm 3.13$ & 1.23 \\
\hline allogroom & 5 & 1 & 5 & 3 & 3 & 0 & 0 & 17 & $2.43 \pm 2.15$ & 0.49 \\
\hline stomp & 0 & 0 & 0 & 0 & 0 & 4 & 3 & 7 & $1.00 \pm 1.73$ & 0.20 \\
\hline avoidance & 0 & 4 & 1 & 15 & 5 & 7 & 10 & 42 & $6.00 \pm 5.23$ & 1.20 \\
\hline posturing & 0 & 0 & 0 & 0 & 0 & 1 & 1 & 2 & $0.29 \pm 0.48$ & 0.06 \\
\hline lunge & 0 & 0 & 0 & 0 & 0 & 0 & 1 & 1 & $0.14 \pm 0.38$ & 0.03 \\
\hline push & 1 & 0 & 2 & 0 & 0 & 0 & 0 & 3 & $0.43 \pm 0.79$ & 0.09 \\
\hline bite threat & 2 & 1 & 7 & 0 & 1 & 0 & 0 & 11 & $1.57 \pm 2.51$ & 0.31 \\
\hline bite & 0 & 0 & 1 & 0 & 0 & 0 & 0 & 1 & $0.14 \pm 0.38$ & 0.03 \\
\hline strike threat & 0 & 0 & 2 & 0 & 0 & 1 & 3 & 6 & $0.86 \pm 1.21$ & 0.17 \\
\hline boxing & 0 & 0 & 4 & 0 & 1 & 3 & 5 & 13 & $1.86 \pm 2.12$ & 0.37 \\
\hline chase & 0 & 0 & 9 & 0 & 0 & 0 & 0 & 9 & $1.29 \pm 3.4$ & 0.26 \\
\hline herding & 0 & 0 & 0 & 0 & 12 & 0 & 0 & 12 & $1.71 \pm 4.54$ & 0.34 \\
\hline defecate over & 2 & 2 & 4 & 0 & 1 & 5 & 5 & 19 & $2.71 \pm 1.98$ & 0.54 \\
\hline flehmen & 5 & 1 & 2 & 2 & 2 & 0 & 0 & 12 & $1.71 \pm 1.7$ & 0.34 \\
\hline play & 2 & 2 & 1 & 0 & 0 & 0 & 0 & 5 & $0.71 \pm 0.95$ & 0.14 \\
\hline body sniff & 2 & 2 & 2 & 0 & 0 & 2 & 1 & 9 & $1.29 \pm 0.95$ & 0.26 \\
\hline displacement & 1 & 0 & 13 & 0 & 2 & 0 & 0 & 16 & $2.29 \pm 4.79$ & 0.46 \\
\hline
\end{tabular}

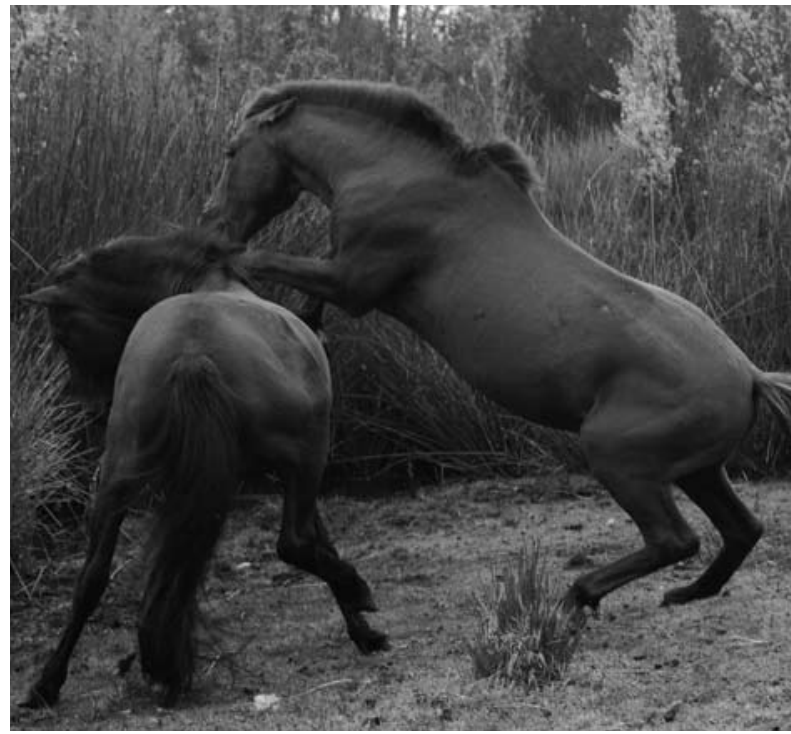

Figure 1. Caballo Fino Chilote stallion lunging against another stallion.

Potro Caballo Fino Chilote embistiendo a otro potro. preliminary overall time budget for the CFCh stallions studied (table 3) can be compared with those described for other breeds as Camargue horses (Kiley-Worthington 1989), draft and light mares (Flannigan and Stookey 2002) and Przewalski horses (Souris et al 2007). There were no significant differences among the days included in the study in relation to the distribution of the behaviours within stallions, and no significant differences $(\mathrm{P}>0.05)$ between the stallions observed.

From the time spent foraging, 54.4\% ( \pm 4.97$)$ was done by grazing and $1.6 \%( \pm 1.15)$ by browsing. Foraging is known to be the main activity of horses, occupying most of their time budgets, and its is characterized by being controlled by a highly regulated motivational system (Fraser 1992). The CFCh stallions spent most of their time in this activity (56\%), percentage similar to that reported by Duncan $(1980,1985)$ for Camargue horses and higher than the $25.83 \% \pm 26.8 \%$ found for densely housed Arab breeding mares by Benhajali et al (2008). The CFCh, being a rustic breed, is capable of adapting to adverse foraging conditions (Escobar et al 1998, Mujica et al 2005), this 
is why time spent browsing was also calculated (1.6\%). The main species available for grazing were Blechnum pennamarina, a common fern in this island, and for browsing Drimys winteri (tree) and Berberis microphylla (bush). Because of the characteristics of these species, it becomes highly important the adjustability of the ingestive behaviour of the CFCh horse, important feature of equines that has been described by many authors (Hintz 1977, Frape 1980).

Resting time was also divided into rest standing $(29 \% \pm 3.92)$ and rest recumbent $(3 \% \pm 2.35)$. This behaviour was the second main activity ( $32 \%$, table 3$)$ in which stallions were involved after foraging, although it tended to follow an opposite trend (figure 2). Percentages reported by Boyd et al (1988) were slightly higher for rest recumbent $(5.3 \%)$ and lower for rest standing (16\%). This could be due to the fact that their study was done over a 24 hour period. Deep sleep occurs in a recumbent position only (McDonnell 2003) which is lower during day time (Boyd et al 1988). According to Boyd et al (1988) a certain amount of recumbency is critical for well being; horses depend on vigilance and speed, and are especially vulnerable while in recumbent rest. Most predators of horses are crepuscular or diurnal, so minimizing recumbency during day time avoids leaving them in a vulnerable position (Boyd 1998).

The mutually exclusive behaviours studied were not equally distributes during the study period. Foraging and resting showed the largest variation during the day. Foraging was significantly lower $(\mathrm{P}<0.001)$ during midday, time at which resting was significantly higher $(\mathrm{P}<0.001)$ compared to the morning and afternoon period. There was a significant higher amount of time spent resting at midday compared to the other periods, the exact opposite occurred for foraging $(\mathrm{P}<0.001)$.

The percentage of time spent in each behaviour, during the 12 hours studied was associated to average temperature (figure 2). Average temperature showed a statistically significant positive correlation with the amount of time spent resting $(r=0.65, P=0.025)$ and a statistically significant negative correlation with the amount of time spent foraging $(\mathrm{r}=-0.67, \mathrm{P}=0.016)$. There were no statistically significant correlations $(\mathrm{P}>0.05)$ between average temperature and the remaining behaviours. Similar correlations were described by Boyd (1998). Horses conserve energy by resting during the hottest hours of the day until it becomes cool enough for them to become active and graze without incurring in thermal stress (Berger 1986) probably this is the reason why stallions used the midday period, when temperatures were higher, for resting. This midday decrease in foraging activity has been observed to disappear during winter (Rubenstein 1981), when energy requirements of horses are probably higher, because of a higher metabolic rate needed to maintain core body temperature, requiring more time engaged in this behaviour (Boyd et al 1988). Even though resting was the main activity during midday, short bouts of foraging also occurred within this period

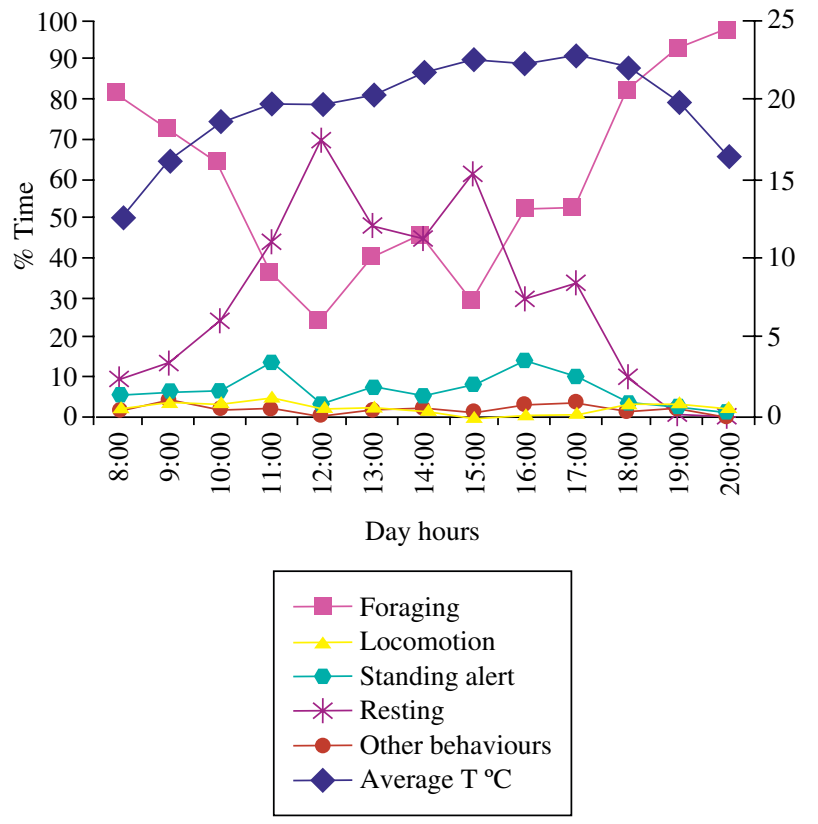

Figure 2. Day time distribution of the five behaviours observed and temperature, averaged by hour and day and subsequently over all five days.

Distribución diaria de los 5 estados conductuales observados y temperatura, datos promediados por hora por el total de días registrados.

(figure 2). Equines salivate as a response to chewing, while production of gastric acids are continues (Harris and Arkell 2005), there fore avoiding long periods of time without feeding enables horses to maintain an adequate gastrointestinal environment and avoid discomfort as a result of excessive acidity.

Locomotion was also found to be constant over the whole observation period, a pattern that was also described by Souris et al (2007). Locomotion is considered an integral part of foraging, since horses are able to keep their heads down ingesting food while taking a step or two (Fraser 1992, McGreevy 2004). In the present study, locomotion was only considered when performed separately from foraging behaviour, otherwise the $2.54 \%$ reported for this activity would be higher.

Even though stallions were enclosed in a reduced area (1ha) the percentage of time involved in standing alert (7.23\%) was consistent with percentages reported by Griffitts (1985) and the Boyd et al (1988) and close to the $11 \%$ reported by Souris et al (2007). A low percentage of the stallion's time was occupied in standing alert and other activities (table 3) compared to other studies (Boyd et al 1988, Boyd 1998, Flannigan and Stookey 2002, Benhajali et al 2008). This could be due to differences in the conditions in which horses were kept and the overall observation hours included in the studies. Because of the range of ages between the stallions in this study (4-13) we expected them to be, more alert and vigilant because of possible agonistic interactions in such a reduced space. 
Table 3. Overall day-time time budget for the seven Caballo Fino Chilote stallions observed over 12 hours for 5 days. Presupuesto de actividad diurno total para los 7 potros Caballo Fino Chilote observados 12 horas diarias por 5 días.

\begin{tabular}{lccccc}
\hline & Foraging & Locomotion & Standing alert & Resting & Other behaviours \\
\hline Percentage of time & 55.89 & 2.54 & 7.26 & 32.40 & 1.86 \\
S.D. & \pm 4.30 & \pm 0.82 & \pm 2.04 & \pm 2.70 & \pm 0.64 \\
Time in minutes & 402.19 & 18.29 & 52.27 & 233.28 & 13.39 \\
\hline
\end{tabular}

Drinking was not included in the behaviours observed in this study because stallions had no ad libitum access to water. Horse's daily water requirements range between 20-70 litres, depending on body weight, air temperature and humidity, level of activity and health (NEWC 2005); Porte (1992) indicates that water requirements can vary between 2.5 and 5 litres for every kilogram of feedstuff or 5-6\% of live body weight. The presence of dew on the grass during early morning and water included in the species foraged were probably an important extra source of water for these stallions. Heat stress is probably not a problem because of the temperate climate of Chiloé Island, compared to the situation of horses kept in arid or tropical areas where average temperatures are higher during summer, as in the case of working horses in Afghanistan, Egypt, India, Jordan and Pakistan (Pritchard et al 2005). According to the NEWC (2005) every horse must have free access to a supply of fresh, clean drinking water to meet its individual maintenance and activity requirements and wellbeing.

Even though the present study has limitations in relation to management conditions and period of observation it gives a first description of some behavioural characteristics of CFCh stallions kept under restricted space and access to water. The distribution of their activities during day time is comparable to those of other free ranging horses, spending the highest amount of time foraging at mornings and afternoons when temperatures are lower. Although agonistic interactions occurred with low frequencies, further studies regarding specific behaviours are needed to be able to classify this breed according to temperament and possible uses, especially in relation to therapeutic work with children.

\section{SUMMARY}

The Caballo Fino Chilote (CFCh) is the only Chilean pony breed and a unique genetic resource. A group of seven CFCh stallions were observed for 60 hours, during summer, at INIA- Butalcura research station, Chiloé Island, under restricted space and access to water conditions. Scan sampling every five minutes was used to register 5 behavioural states and continuous focal sampling for 19 behavioural events. Inter-male interactions had a low frequency of presentation being avoidance (1.2 average events per stallion per day) the most common Overall stallions spent $55.89 \%( \pm 4.3 \%)$ of their time foraging, $2.5 \%$ $( \pm 0.82 \%)$ in locomotion, $7.26 \%( \pm 0.82 \%)$ standing alert, $32.24 \%$ $( \pm 2.7 \%)$ resting and $1.86 \%( \pm 0.64)$ in other behaviours. Foraging was the main activity, its occurrence was significantly lower $(\mathrm{P}<0.05)$ during midday, time when resting was significantly higher $(\mathrm{P}<0.05)$ compared to the morning and afternoon periods. Locomotion, standing alert and other behaviours had a constant distribution during the day. A significant positive correlation between temperature and resting was found while there was a significant negative correlation between temperature and foraging. The present study is a first attempt in describing behavioural characteristics of CFCh stallions. Distribution of their activities during day time is comparable to those of other free ranging horses. Emphasis is made on the fact that the restricted access to water, that these horses were subjected to, is of ethical concern and a risk for their wellbeing. More studies in relation to behaviour are needed in order to classify this breed according to temperament and possible uses.

\section{ACKNOWLEDGEMENTS}

The authors would like to acknowledge INIA-Butalcura for allowing us to undertake this study at their facilities, and CONICYT for the funding of the Doctor in Veterinary Science degree.

\section{REFERENCES}

Barrera M. 1998. Parámetros morfológicos y tipificación de polimorfismos antigénicos eritrocitarios y bioquímicos como base del stud book de la raza Caballo Chilote. Tesis de Licenciatura, Escuela de Medicina Veterinaria, Universidad Austral de Chile, Valdivia, Chile.

Benhajali H, MA Richard-Yris, M Leroux, M Ezzaouia, F Charfi, M Hausberger. 2008. A note on the time budget and social behaviour of densely housed horses. A case study in Arab breeding mares. Appl Anim Behav Sci 112, 196-200.

Berger J. 1986. Wild horses of the Great Basin, social competition and population size. The University of Chicago Press, Chicago, USA.

Boyd LE, DA Carbonaro, KA Houpt. 1988. The 24-hour time budget of Przewalski horses. Appl Anim Behav Sci 21, 5-17.

Boyd LE, KA Houpt. 1994. Activity patterns. In: Boyd L, KA Houpt (eds). Przewalski's Horse: the history and biology of an endangered species. State University of New York Press, Albany, USA, Pp 195-254.

Boyd LE. 1998. The 24-h time budget of a takh harem stallion (Equus ferus przewalskii) pre and post reintroduction. Appl Anim Behav Sci 60, 291-299.

Cabrera A. 1945. Caballos de América. Editorial Sudamericana. Buenos Aires, Argentina.

Carroll CL, PJ Huntington. 1988. Body Condition Scoring and Weight Estimation of Horses. Equine Vet J 20, 41-45.

Christensen JW, T Zharkikh, J Ladewig, N Yasinetskaya. 2002. Social behaviour in stallion groups (Equus przewalskii and Equus caballus) kept under natural and domestic conditions. Appl Anim Behav Sci 76, 11-20.

Cothran G, R Mansilla, J Oltra, M Ortiz. 1993. Análisis genético del caballo Chilote de Isla de Chiloé-Chile. Arch Med Vet 25, 137-146.

Crowel-Davis SL. 1983. The behaviour of Welsh pony foals and mares. $P h D$ thesis, Cornell University, Ithaca, New York, USA. 
Duncan P. 1980. Time-budgets of Camargue horses. II. Time-budgets of adult horses and weaned sub-adults. Behaviour 72, 26-49.

Duncan P. 1985. Time-budgets of the Camargue horses. III. Environmental influences. Behaviour 72, 26-49.

Escobar A, J Oltra, M Ortiz, J Voeltz. 1998. Caballo Chilote. FAO Animal Genetic Resources Information 23, 41-47.

Escobar A, T Tadich. 2006. Caracterización biocinemática, al paso guiado a la mano, del Caballo Fino Chilote. Arch Med Vet 38, 53-61.

FIA, Fundación para la Innovación Agraria. 2000. Proyecto: Recuperación y multiplicación del caballo chilote.

Flannigan G, JM Stookey. 2002. Day-time time budget of pregnant mares housed in tie stalls: a comparison of draught versus light mares. Appl Anim Behav Sci 78, 125-143.

Frape DL. 1980. Facts about feeding horses. Practice 21, 14-21.

Fraser AF. 1992. Maintenance behaviour. In: The behaviour of the horse. Charper 3. CABI Publishing, Wallingford, UK, Pp 78-83.

Griffits C. 1985. The behaviour of Przewalski horses at the Denver Zoo. Thesis, Department of Animal Science, Cornell University, Ithaca, New York, USA.

Harris PA, K Arkell. 2005. How understanding the digestive process can help minimize digestive disturbances due to diet and feeding practices. In: Harris PA, Mair TS, Slater JD, Green RE (eds). Equine nutrition for all. Proceedings the ist BEVA and Waltham nutrition symposia, Harogate, UK.

Hintz HF. 1977. Nutrition of the Horse. In: Evans JW, Borton A, Hintz HF, Van Vleck LD (eds). The Horse. Freeman, San Francisco, USA, Pp 239-347.

Kaseda Y. 1983. Seasonal changes in time spent grazing and resting of Misaki horses. Jpn J Zootech Sci 54, 464-469.

Kiley-Worthington M. 1989. Feeding behaviour and digestion. In: The behaviour of horses in relation to management and training. Chapter 7. JA Allen, London, UK, Pp 151-159.

McDonnell S. 2003. The equid ethogram, a practical field guide to horse behaviour. The Blood Horse Inc., Hong Kong, China, Pp 23-89.

McGreevy P. 2004. Ingestive behavior. In: Equine behavior, a guide for veterinarians and equine scientists. Chapter 8 . Saunders, Philadelphia, USA, Pp 189-216.
Mujica F, V Obreque, P Hinrichsen, G Cothran. 2005. Recuperación, conservación y caracterización del Caballo Chilote. Agro Sur 33, 58-67.

NEWC, National Equine Welfare Council. 2005. Equine industry welfare guidelines compendium for horses, ponies and donkeys. $2^{\text {nd }}$ ed. Oxfordshire, UK.

Pereira JR, SSS Vianna. 2006. Gastrointestinal parasitic worms in equines in the Paraíbo Valley State of Sao Paulo, Brazil. Vet Parasitol 140, 289-295.

Pinochet JL. 1980. Estudio hipométrico y morfológico del caballo de raza criolla chilena y su posible cambio tipológico. Tesis de Licenciatura, Escuela de Medicina Veterinaria, Universidad de Chile, Santiago, Chile.

Porte E. 1992. Equino de tiro. Editorial Universitaria S.A., Santiago, Chile.

Pritchard JC, AC Lindberg, DCJ Main, HR Whay. 2005. Assessment of the welfare of working horses, mules and donkeys, using health and behaviour parameters. Prev Vet Med 69, 265-283.

Rubenstein DI. 1981. Behavioural ecology of island feral horses. Equine Vet $J 13,27-34$.

Salter RE, RJ Hudson. 1979. Feeding ecology of feral horses in Western Alberta. J Range Manage 32, 221-225.

Sánchez A, R Morales. 2000. Décima Región de los Lagos. En: Las regiones de Chile. Espacio físico y humano económico. Editorial Universitaria, Santiago, Chile.

Schoen AMS, EM Banks, SE Curtis. 1976. Behaviour of young Shetland ponies (Equus caballus). Biol Behav 1, 199-216.

Souris AC, P Kaczensky, R Julliard, C Walzer. 2007. Time budget, behavioral synchrony and body score development of a newly released Przewalski's horse group Equus ferus przewalskii, in the Great Gobi B strictly protected area in SW Mongolia. Appl Anim Behav Sci 107, 307-321.

Sweeting MP, CE Houpt, KA Houpt. 1985. Social facilitation of feeding and time budgets in stabled ponies. J Anim Sci 60, 369-374.

Voeltz J. 1996. Descripción morfológica del Caballo Chilote y su distribución en la Isla de Chiloé. Tesis de Licenciatura, Escuela de Medicina Veterinaria, Universidad Austral de Chile, Valdivia, Chile. 